\title{
THE KRUGER NATIONAL PARK
}

\section{By Lieut.-Colonel J. Stevenson-Hamilton}

The Kruger National Park, together with the less known national parks of the Union of South Africa, is governed by a Board of ten unpaid Trustees, ultimately responsible to the Minister of Lands. This Board maintains a considerable bureaucratic staff under a paid secretary, with offices in Pretoria. Attached to it are various salaried scientific experts, zoologists, botanists, and others, with such personal staffs as may be found necessary.

In the Park itself, and subordinate to the Pretoria bureaucracy, is stationed the administrative staff, consisting of a Warden, with his office staff of European clerks and typists, and under him eight district European rangers, each with his own quota of native police. At Park headquarters is also the office of the Chief Tourist Officer, with office staff, and under his control during the open season about a dozen European camp and entrance gate officers. In addition, there is an officer in control of roads and transport and another in charge of buildings, besides mechanics, storemen and others. Besides the force of police or native rangers Africans are employed as lorry and tractor drivers, camp attendants, builders, thatchers, and for road making and all other manual work.

One may judge, therefore, that the Board has at its disposal for the Kruger Park a number of employees sufficient to ensure efficiency in every respect.

The catering for the dozen or so tourist rest camps, sale of petrol, oil and all other visitors' requisites is let out to a firm of contractors, who maintain their own staff of European and native employees.

There is a government subsidy of about $\mathfrak{E 1 5 , 0 0 0}$ per annum, and it is understood that the revenue from the tourist traffic

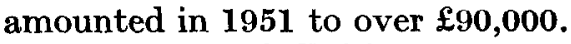

Yet in spite of all this apparent prosperity and efficiency there have been increasing complaints in the last few years from the visiting public of growing inadequate amenities and progressive decrease in the wild animals which, after all, are what they came long distances to see. In certain portions of the Park, where the grass may grow to a height of six feet or more, it is obvious that even if animals were present it would be impossible to see anything of them, the view being completely obscured.

That there has been a considerable reduction in the numbers of the grazing antelopes in recent years I think there can be no 
reasonable doubt. Of the area known as Pretorius Kop, which because it lies outside the recognized malaria zone is open to visitors all the year round, there was a little doggerel rhyme used in early days for advertisement purposes :-

"Pretorius Kop where the wild beasts abound

The cream of the Park open all the year round."

However true this description may have been ten or even five years ago, it hardly fits the picture to-day, when one may travel for miles without seeing a single living animal. Letters in the Press and verbal remarks by returned visitors seem to indicate a similar condition in other portions also.

Various reasons are advanced for this apparent deterioration. Among them :-

Several successive seasons of drought.

The prohibition of all grass burning.

The spread of dense thorn bush, to the detriment of grazing.

Prohibition of the control of carnivorous animals.

Increase of native poaching from outside.

Drought.-There has always been a tendency in the drier part of the year for game to wander westwards, where the food and water is more abundant. Such annual emigrations now take them outside the Park on to privately owned lands or native reserves, with inevitable consequences. To alleviate drought conditions the Warden, Colonel Sandenbergh, personally appealed for funds to the public, with such good results that a number of bore-holes and dams were constructed, without any expense to the Board. This can be regarded however only as a palliative, though a useful one.

Grass Burning.-This is a much disputed point. It is now accepted as axiomatic that grass burning on farm land is pernicious, in that it, among other evils, destroys young tree shoots and causes erosion. Where however farming is not in question, but simply the attraction for grazing (and browsing) antelopes, other factors must be considered.

Antelopes, except species such as reedbuck, duiker and small kinds which exist through concealment, will not stay in long grass if there is anywhere else to go because :-

(a) They fall an easier prey to their natural enemies while thus obstructed.

(b) The long, hard, dry stems offer little or no nutriment.

(c) Long grass, especially when wet, cuts their legs and pasterns when moving through it at speed.

(d) Long grass swarms with ticks and other insect vermin. 
Therefore when private owners and natives living just beyond the Park borders desire to tempt game to come over to their side, they set fire to their own grass, knowing that with a few weeks the fresh green shoots will prove an irresistible attraction.

A scientific theory in favour of keeping the grass long is that after a period of years, it will stifle the growth of the ubiquitous thorn bush and eventually greatly increase the grazing area. Whatever truth there may be in this contention appears largely discounted by the probability that if and when the enhanced grazing has become available there will be no animals left to benefit by it !

On the whole, it seems to me that when we are not primarily concerned with farming, but with the preservation of wild animals, a prudent policy of controlled burning of grass over a year old is the best plan. Sections of country burnt in the late summer or early autumn will carry young grass, stimulated by late autumn showers, throughout the winter ; fires started then do not spread, but are extinguished nightly by heavy dews or rain. About half the veldt should be left untouched till the following year, and so on in rotation. If, on the other hand, all the old grass remains unburnt, there is a strong probability that sooner or later devastating fires, lighted beyond the borders, and driven before a high wind, will sweep through and wreak great destruction over immense areas.

I do not think it is quite correct to say that leaving all old grass unburnt is to follow nature. For tens of thousands, perhaps hundreds of thousands of years, in fact ever since primitive man first discovered how to make and use fire, grass fires have undoubtedly been purposely lighted, whenever it suited savage man for hunting or other purposes. They have almost become a provision of nature in a wild country, and the animals have adapted themselves accordingly.

These are of course just personal views, but they are supported-as any observer can see for himself-by the fact that the larger antelopes will not, if they can help it, remain in long grass but will flock on to patches where it has been eliminated and where they can get at the new growth.

Spread of Thorn Bush.-The secondary forest composed of dwarf acacia, which covers so much of the Kruger Park and varies greatly in density, is favourable to browsing species, kudu, impala, nyala, but the grazers, such as wildebeeste, tsessebe, roan and sable antelope, are allergic, and as the bush spreads so do they retreat. 
As the browsers spread so of course does the kind of bush which they favour. I think the great increase of impala during the last twenty-five years-largely due to some epidemic which nearly exterminated their principal enemy, the African hunting $\operatorname{dog}-$ was responsible for the great spread of acacia bush in the same period. Impala are fond of the bean pods of certain types of acacia, and these, passed with the droppings, soon spring up. Bush fires will destroy the seedlings, but the well-grown acacia bush has established a complete fire immunity, further evidence to show that bush fires have been of very long standing.

Control of Carnivora.- Undoubtedly in seasons of drought, when the water pools dry up and the antelope herds are crowded round the few drinking places that remain, the larger carnivora also concentrate, and take very high toll. On the other hand, when a succession of good years follows, with plenty of grazing and water, game scatters widely and lions have a hard time, especially as they may have disproportionately increased during the (for them) good years. Their struggle for existence then becomes difficult, many young lions are killed by their older companions, while the females have difficulty in feeding their cubs, and many of the latter succumb to poverty and rickets. Undoubtedly under truly natural conditions nature, if left alone, can be trusted to strike a true balance through the years. In a circumscribed area however, whence game constantly strays and falls victim to human agency, it is perhaps necessary to exercise some control over such animals as lions and hunting dogs. This is a matter which cannot be dogmatically decided by authorities residing at a distance but must be left to those on the spot, who alone can judge of varying local requirements from time to time. At the present time, when from general accounts there seems to be really an alarming decrease in several species of the antelope population, this may have assumed importance. Up to 1926 when the Board of Trustees assumed control of Kruger Park from the Transvaal Administration, the control of carnivora and all other matters affecting the animals were left entirely in the discretion of the Warden and his staff, with satisfactory results.

Increase of Native Poaching.-The country which composes the Kruger Park consists of immense areas of uninhabited bush and savannah, traversed here and there by roads-roads which, from the air, look like tiny threads amid an immense sea of close-growing trees. Here white officers, confined by their motor transport to the roads and their immediate vicinity, can know little of what really goes on a few miles away. Native rangers in distant isolated posts or on patrol require constant supervision, 
for their sense of duty, excellent as it formerly was and no doubt still is, may be subject to severe tests. Except for a block of farms where the owners carefully preserve the game, the Park is surrounded by natives, all belonging to tribes in whom hunting is hereditary-Union subjects on west and south, Portuguese on east. In order freely and constantly to patrol his district, which consists often of dense thorn bush or rocky pathless hills, a supervising officer requires something other than mechanized transport. With a horse and a few pack donkeys he can go anywhere, appearing in the most unexpected places, and only thus equipped can he hope to know his area as he should. Otherwise one feels that the factor of extensive native poaching, especially in inaccessible places far from any road or track, cannot be ruled out. After World War I, during which the ranger and police staff were cut by 50 per cent, it was found that gangs of professional native hunters had established semipermanent camps up to distances of $\mathbf{2 0}$ miles inside the sanctuary. Many buffaloes and giraffes, as well as antelopes, had been killed and the meat dried and removed without interference.

I have made the above remarks merely as possible explanations of the apparent decrease in the numbers of certain antelope species, according to the expressed opinions of some of the visiting public. But since visitors are necessarily confined to the roads and to their cars, their views and judgment cannot always be relied upon. It is however obviously of the first importance that visitors' discontent should not spread, for the existence of the sanctuary depends entirely upon its popularity, and if the game decreases too much the lions will disappear without any extraneous aid. But matters should not be allowed to go so far. Probably 75 per cent of the people who visit the Park annually do so mainly to see the lions.

An American traveller in Africa, Mr. Fred A. Wardenburg, in his book Safari Encore, compares the Kruger Park most unfavourably with other places he has seen. I think he writes rather unfairly, for he spent only a couple of days driving round Pretorius Kop at the worst time of the year. Here, without doubt, the old long grass would obstruct the view and make a bad impression upon a critical stranger. Unfortunately, such impressions are apt to spread.

As with most organizations, the more authority and freedom of judgment given to those who live on the spot the better. The less centralization there is and the less control by non-resident authorities the greater is the efficiency and the less the expense. 


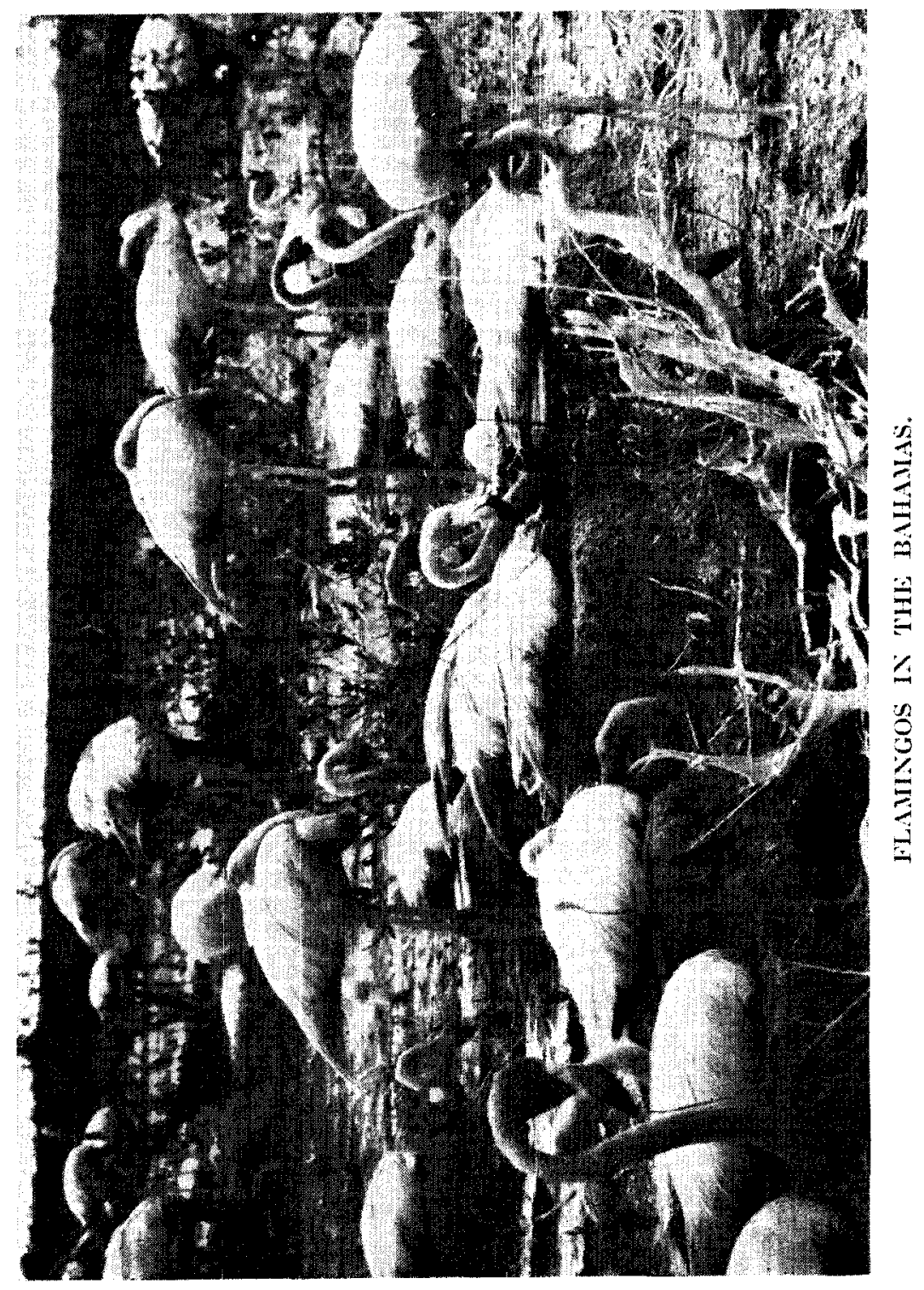

